
\title{
Research S Surate \\ The bacterial communities of Alaskan mosses and their contributions to nitrogen fixation
}

Hannah Holland-Moritz

Julia E. M. Stuart

Lily R. Lewis

Samantha N. Miller

Michelle C. Mack

Jose Miguel Ponciano

Stuart F. McDaniel

Noah Fierer

\section{Video Byte}

Keywords: Bryophytes, plant microbiome, phyllosphere, nitrogen fixation, Alaska, moss, nitrogen,

Microbiome

Posted Date: March 11th, 2021

DOI: https://doi.org/10.21203/rs.3.rs-318778/v1

License: (c) (i) This work is licensed under a Creative Commons Attribution 4.0 International License.

Read Full License 


\section{Abstract}

Mosses are ubiquitous in northern ecosystems. Their critical ecological roles include insulating soils, maintaining soil moisture, and mediating carbon and nitrogen cycles. Like all plants, mosses associate with microbes and some of them are key contributors to nitrogen dynamics through their nitrogen fixation functions. To better understand the importance of moss host species and environmental factors in structuring these microbial communities, researchers studied 26 boreal and tundra moss species across 24 sites in Alaska. They found that both host species and host evolutionary history predicted moss microbiome composition, and microbe nitrogen fixation rates also varied by host species. To a lesser extent, light availability and temperature also influenced the composition and function of moss microbes. Finally, they identified putative nitrogen-fixing bacteria specific to some moss hosts, including some outside well-studied cyanobacterial clades. These results demonstrate the utility of mosses as a model system for understanding plant-microbe interactions in non-leguminous systems and highlight the importance of novel bacterial taxa to nitrogen fixation in high-latitude ecosystems. Future studies will focus on isolating moss-residing microbes to better study the processes controlling nitrogen fixation rates. 